\title{
Causes and Consequences of Cohabitation among Students of Federal Polytechnics Offa, Kwara State, Nigeria
}

\author{
Senior Lecturer Department Of Social Sciences Education, Faculty Of Education, Universitas Of Ilorin \\ Bello Bolanle Muhinat \\ Email : bello.mb@unilorin.edu.ng
}

\begin{abstract}
The culture of chastity and purity is no longer promoted and encouraged among the youths, especially those who are out for school in tertiary institutions. This study, therefore, investigated the Causes and Consequences of Cohabitation among Students of Federal Polytechnic Offa, Kwara State, Nigeria. A descriptive survey was adopted for the study where 200 students from OND2 and HND2 were purposively chosen and then selected at random. A researcher designed a questionnaire in a Likert scale of Strongly Agree, Agree, Disagree and Strongly Disagree containing 16 items but divided into two halves into causes and consequences of cohabitation was the instrument used for the collection of data. The data was validated via experts and the test-retest method was used to arrive at a reliability index of 0.69. The data was analysed using descriptive statistics. Mean ratings of simple percentages were used to answer the research questions. Causes of cohabitation were seen to include among others insufficient on-campus accommodation, financial distress, fear of losing loved ones, moral and religious decadence while death, STDs, drop out of school poor academic performance and health or social issues were seen as some of the consequences of cohabitation. It was recommended among others that the school authority should try to provide sufficient on-campus accommodation for the students.
\end{abstract}

Keywords : Cohabitation; Students; Causes; Institution; Consequences.

\begin{abstract}
Budaya kesucian dan kesucian tidak lagi dipromosikan dan didorong di kalangan pemuda, terutama mereka yang bersekolah di perguruan tinggi. Oleh karena itu, penelitian ini menyelidiki Penyebab dan Konsekuensi Kohabitasi di antara Siswa Politeknik Federal Offa, Negara Bagian Kwara, Nigeria. Sebuah survei deskriptif diadopsi untuk penelitian di mana 200 siswa dari OND2 dan HND2 dipilih secara sengaja dan kemudian dipilih secara acak. Seorang peneliti merancang kuesioner dalam skala Likert Sangat Setuju, Setuju, Tidak Setuju dan Sangat Tidak Setuju yang berisi 16 item tetapi dibagi menjadi dua bagian menjadi penyebab dan konsekuensi dari hidup bersama adalah instrumen yang digunakan untuk pengumpulan data. Data divalidasi melalui ahli dan metode tes-tes ulang digunakan untuk sampai pada indeks reliabilitas 0,69. Analisis data menggunakan statistik deskriptif. Rata-rata peringkat persentase sederhana digunakan untuk menjawab pertanyaan penelitian. Penyebab kohabitasi terlihat termasuk antara lain akomodasi di kampus yang tidak memadai, kesulitan keuangan, ketakutan kehilangan orang yang dicintai, dekadensi moral dan agama saat kematian, PMS, putus sekolah, prestasi akademik yang buruk dan masalah kesehatan atau sosial dilihat sebagai beberapa dari konsekuensi dari hidup bersama. Direkomendasikan antara lain bahwa otoritas sekolah harus berusaha menyediakan akomodasi di kampus yang memadai bagi para siswa.
\end{abstract}

Kata Kunci : Kohabitasi; Siswa; Penyebab; Institusi; Konsekuensi. 


\section{PRELIMINARY}

Generally speaking, the way things are done these days is certainly not the same way they were done in the past and these changes are found in all spheres of life which culture is not an exception. The culture of chastity and purity is no longer promoted and encouraged among the youths. Some things that were not present in our society are now obtainable in our society. One of such is cohabitation. Cohabitation means to live together, and have a sexual relationship or to live together as though married couples. Cohabitation in Nigeria among youths is becoming a new normal as it's not difficult to see adults stay together even if they are not married. The rate at which youths cohabit these days call for concerns as one would be left with no choice but to be wondering what has become of our society. It is observed that the trend gets worse when students leave their homes, knowing fully well that they are not under the watch of their parents/guardians or they are where not many people knew them. Cohabitation has become to some tertiary institution students: a new normal and some purposely refuse to stay on campus, owing to the fact they are gaining their freedom for the first time. Admission to a higher Institution is considered liberty and freedom to do whatever they like.

The Federal Polytechnic Offa is one of the federal institutions in Kwara state established in 1992. The polytechnic runs both the National Diploma (ND) and Higher National Diploma (HND) programs as well as part-time and IJMB programs. At present, the institution has 26 departments with several students and staff; academic and non-academics (Federal Polytechnic Offa, 2021 However, with this growing population, the students of the polytechnic are assumed to have been left with no choice but to make do with the available houses within the community (Offa) which contains 100,000 and more inhabitants and as a result, some of them are believed to be staying with others, even to the extent of the female staying with their male friends in the name of insufficient on-campus or in-school accommodation or inability to afford the available ones. Of truth, there is no sufficient accommodation in the school to house all the students as the institution continues to expand its departments but some hostels are written from immunity and nearby villages that students can stay at to study at the institutions. However, maybe for reasons like distance, fear, financial distress, and the likes, some of these students decide to cohabit and this calls for concerns as the student's affairs department of the institution has recently recorded a high number of cases between and among students staying together in the name of cohabitation.

in their study Factors influencing cohabitation among undergraduate students of Federal University of Technology Minna, Niger State, Nigeria: implications for counselling stated the factors influencing the prevalence of cohabitation among students as including inadequacy of school hostel accommodation since cohabitation is not possible on-campus accommodation, lack of money or resources to pay as at when due thereby creating the opportunity for students who have resources to lure poor students to stay with them, peer influence or pressure, inability to manage or control sexual urges or desire for sexual satisfaction, etcetera, Jiya and Alhassan (2019). Other causes may include the fear of losing out on a partner or loved one, greed, extravagance or desire to live large while on campus, fear, among others. In the end. cohabitation and premarital sex have become kinds of passports to acceptance in a particular age group (Ekpenyong and Ekpenyong, 2016). Also, Jiya and Alhassan (2019) in another study on cohabitation stated that inadequate hostel accommodation, financial challenges faced by students (most especially female students), peer pressure, lack of supervision by parents (under the guise that students have "grow the use of erotic sexual films and magazines etc are the causes or influencing factors of cohabitation among tertiary institution students. Freedom from Parental Supervision, loss of religious inclination, abandonment of valued African culture, sexual gratification, financial distress, to study each other for marriage, shortage of on-campus accommodation, and higher tuition fees were the factors responsible for cohabitation among tertiary institution students (Onoyase, 2020).

The culture of cohabitation, which cannot be differentiated from premarital sex, remains on an upward swing among adults and youths, including undergraduate students in many tertiary institutions of the nation. It is $\mathrm{n}$ ot believed that globalization, urbanization and civilization have 
aided the spread of this phenomenon in Nigerian tertiary institutions and it has become a subject of concern to researchers, especially sociologists, practitioners of couples therapy or couples education, as well as parents, and other stakeholders in the education industry (Duyilemi, Tunde-Awe, Adekola 2018). Cohabitation occurs when a couple chooses to live together and form a romantic relationship while remaining unmarried. Researchers began paying more attention to this living situation as the number of cohabiting couples began increasing since the turn of the century. Researchers differentiate the types of cohabitation in their studies (Adeniyi, 2019) such as limited cohabitation, premarital cohabitation, substitute marriage cohabitation, no alternative cohabitation, and convenient cohabitation. Whatever the reason, the consequences and whichever type of cohabitation that the students of Federal Polytechnic Offa are involved in remains to be investigated and that has prompted this study.

\section{Statement of the Problem}

At the student affairs unit of the polytechnic, many cases have been reported by cohabiting students who at first present it differently but upon investigation ends up to be that they were cohabiting and hence such occurrence. Many students tend to lose sight of why they are in school and are preoccupied with unnecessary issues, these cause lots of distractions for many students and make them perform below expectations. Cohabitation has become rampant that students have become promiscuous, it has led to unwanted pregnancies which have affected their completion of education. Female student goes for abortion which exposes them to risk of death or damaged uterus. Another problem is the threat of sexually transmitted diseases such as HIV/AIDS etc and the use of oral contraceptives by female students to avoid pregnancy can leads to health issues that shortened the educational aspiration. Students of the polytechnic and other tertiary institutions alike in Nigeria see cohabitation as nothing bad as the majority of them are noticed to be happily involved in this act. Many tertiary institution students nowadays are found to be involved in cohabitation as many of them in a way or the other seize the opportunity of being alone to do things they ordinarily cannot do. Other students may have different reasons for cohabiting but whatever the reason, cohabitation has its consequences. It is common to see male and female students moving together both on and off-campus as some of them are even known among their friends as been married to each other while they are truly not but are called so because of cohabitation. Some of the end of the relationship.

A lot of researches have been conducted on the causes, consequences and prevalence of cohabitation among tertiary institution students. For instance, Arisukwu (2014) opined that students indulge in cohabitation for pragmatic considerations to save money on rent and other living expenses. That is, they cohabit with those whom they perceive are capable of solving their financial problems. Other reasons or forms of support that may make students cohabit include academics, emotional stress, and social engagement (Duyilemi, Tunde-Awe, Adekola, 2018). Some researchers opined that cohabiters cohabit to study each other and test compatibility with their partners, while they still have the option of ending the relationship if things turn sour or do not work in their favour. Accordingly, Elise (2004) revealed that in the US, cohabitation is often seen as a natural step in the dating process as more than two-thirds of married couples were said to have cohabited (lived together) before getting married. Among students, Risman, Hill, Rubin and Peplau (1981) maintained that cohabitation is a stage of courtship. Thus, cohabitation is viewed as a prelude to marriage or as an important antecedent to marriage. As revealed by Bumpass and Lu, (2000), almost 60 per cent of all marriages formed had begun as non-marital unions. However, a survey by a University of Chicago sociologist Linda Waite found that 16 per cent of cohabiting women reported that arguments with their partners became physical, while only 5 per cent of married women had similar experiences.

Consequences of cohabitation among tertiary institution students abound. Adeniyi (2019) conducted a study on The effects of cohabitation on the academic performance of students in tertiary institutions in Nigeria, the study revealed that cohabitation breeds abortion, sexually 
transmitted diseases, and some even tend to indulge in social vices like stealing, lying and cybercrimes to raise finances to keep their affairs going. In addition, at times, the females are more often than not abused and molested by their partners or "would-be husbands" when they quarrel or have a fight, leading to grave psychological trauma that could affect their health, social life and education while some of the students who cohabit find it difficult to graduate and make lower grades because they do not have enough time to read. The majority often withdraw from or are been dismissed from school, while some involve in death, depression and suicidal attempts, others spend longer time than necessary as a result of carryovers (Adeniyi, 2019). Ojewole and Okinduyo (2017) in a study on Prevalence and Factors Responsible for Cohabitation among Undergraduates of Adekunle Ajasin University, Ondo State quoted the above factors but also included religion. Despite all the efforts by researchers, none of the studies has been conducted in polytechnic and none in a university in Kwara state while the incidence of cohabitation persist among students in higher institutions as it is evident among students of Federal Polytechnic Offa, Kwara state and this necessitated this study as the researcher is interested to find out whether or not they have different or similar reasons for cohabitation.

Purpose of the Study

The study examined the Causes and Consequences of Cohabitation among Students of Federal Polytechnic Offa, Kwara State, Nigeria. Specifically, the study;

a. examine the causes of cohabitation among students of federal polytechnic Offa, Kwara state; and

b. evaluate the consequences of cohabitation among students of federal polytechnic Offa, Kwara State

\section{Research Questions}

This study address the following research questions;

a. what are the causes of cohabitation among students of federal polytechnic Offa, Kwara state?

b. what are the consequences of cohabitation among students of federal polytechnic Offa Kwara state?

\section{RESEARCH METHODS}

The researcher employed the descriptive survey method. Daramola (2006) describes the descriptive research survey as the systematic attempt to describe the characteristics of a given population or areas of interest factually. It looks critically at phenomena and describes it the way it is without adding anything. That is, it avails the researcher the researchers the opportunity to determine and report phenomena the way they are, without altering any part or the whole of it. Equally, the researcher considers the survey type as most suitable for this study because it would avail the researcher that needed opportunity to describe accordingly the concept of prevalence of cohabitation among students of federal polytechnic Offa. The population of this study comprised all the students of Federal polytechnic Offa, Kwara State. The sample of the study was 200 National Diploma (ND) two (2) and Higher National Diploma (HND) two (2) students who were purposively selected at random since they were believed to have stayed in the school for at least two (2) years and should have a better knowledge of the concept under study even if they may not be involved in 
it themselves. Accordingly, 100 of the respondents would each be drawn from the lower and upper tiers of the school (ND2 and HND 2) respectively.

The instrument for the collection of data for this study was a researcher designed questionnaire entitled "causes and Consequences of Cohabitation among Students of Federal Polytechnic Offa"(PCAS). It was distributed to the respondents to gather the needed information from them. The questionnaire was on Likert's scale with four (4) options of Strongly Agreed, Agreed, Disagree and Strongly Disagree response. The questionnaire contained eight items on causes of cohabitation and eight items on consequences of cohabitation, totalling 16 items. The validity of the instrument was content while the reliability index 0.69 , after a test-retest method. The data collected for this study were analysed using descriptive statistics. A frequence and percentage was used to answer the research questions.

\section{RESULTS AND DISCUSSION}

\section{a. Results}

The findings of the study were presented thus;

Research Question 1: What are the causes of cohabitation among students of federal polytechnic Offa, Kwara state?

\section{Table 1: Percentage of causes of Cohabitation}

\begin{tabular}{lllllll}
\hline $\mathbf{S / N}$ & Items & SA(\%) & $\mathbf{A ~ ( \% )}$ & $\mathbf{D ~ ( \% )}$ & SD (\%) & Decision \\
\hline $\mathbf{1}$ & $\begin{array}{l}\text { Insufficient on-campus accommodation } \\
\text { has led some students to cohabitation }\end{array}$ & $52(26)$ & $76(38)$ & $64(32)$ & $08(04)$ & Agreed \\
$\mathbf{2}$ & $\begin{array}{l}\text { Fear of losing lover also necessitates } \\
\text { cohabitation }\end{array}$ & $84(42)$ & $104(52)$ & $12(06)$ & $00(00)$ & Agreed \\
$\mathbf{3}$ & $\begin{array}{l}\text { Freedom and lack of monitoring by } \\
\text { parents/guardian leads to cohabitation } \\
\mathbf{4}\end{array}$ & $80(40)$ & $112(56)$ & $08(04)$ & $00(00)$ & Agreed \\
$\mathbf{5} \quad \begin{array}{l}\text { Fear or insecurity in the school area also } \\
\text { brings about cohabitation }\end{array}$ & $76(38)$ & $100(50)$ & $16(08)$ & $08(04)$ & Agreed \\
$\mathbf{6}$ & $\begin{array}{l}\text { Some students are cohabiting due to } \\
\text { poverty or financial distress }\end{array}$ & $44(22)$ & $72(36)$ & $80(40)$ & $04(02)$ & Agreed \\
$\begin{array}{l}\text { Desire to practice living as married } \\
\text { couples push some students into } \\
\text { cohabitation! }\end{array}$ & $32(16)$ & $104(52)$ & $56(28)$ & $08(04)$ & Agreed \\
$\mathbf{7}$ & $\begin{array}{l}\text { Decline in moral and religious values is } \\
\text { also a cause of cohabitation }\end{array}$ & $36(18)$ & $88(44)$ & $72(36)$ & $04(02)$ & Agreed \\
$\mathbf{8}$ & $\begin{array}{l}\text { Laziness among some students is also } \\
\text { responsible for their cohabiting habits }\end{array}$ & $28(14)$ & $88(44)$ & $76(38)$ & $08(04)$ & Agreed \\
\hline
\end{tabular}

From table 1, all the causes of cohabitation among students of Federal Polytechnic Offa highlighted were agreed upon by the respondents wit percentage of agreed ranges from 58-96.

Research Question 2: what are the consequences of cohabitation among students of federal polytechnic Offa Kwara state?

Table 2: Percentage of Consequences of cohabitation

\begin{tabular}{|c|c|c|c|c|c|c|}
\hline$S / N$ & Items & SA(\%) & $A(\%)$ & D (\%) & SD (\%) & Decision \\
\hline 1 & $\begin{array}{l}\text { Contacting sexually transmitted infections is } \\
\text { easy among cohabiting students }\end{array}$ & 84 (42) & $80(40)$ & $36(18)$ & $00(00)$ & Agreed \\
\hline 2 & $\begin{array}{l}\text { Unexpected pregnancies are common among } \\
\text { cohabiting couples, thus leading to abortion }\end{array}$ & $76(38)$ & $124(62)$ & $00(00)$ & $00(00)$ & Agreed \\
\hline
\end{tabular}




\begin{tabular}{|c|c|c|c|c|c|c|}
\hline 3 & $\begin{array}{l}\text { Abortion by a cohabiting person may lead to } \\
\text { complications and eventually death }\end{array}$ & $108(54)$ & $72(36)$ & $20(10)$ & $00(00)$ & Agreed \\
\hline 4 & $\begin{array}{l}\text { Some students may end up dropping out of } \\
\text { school due to their inability to provide for their } \\
\text { needs and that of their partners }\end{array}$ & $92(46)$ & $104(52)$ & $04(02)$ & $00(00)$ & Agreed \\
\hline 5 & $\begin{array}{l}\text { Joining bad gangs to keep up with such a } \\
\text { lifestyle is common among cohabiting students }\end{array}$ & $56(28)$ & $128(64)$ & $16(08)$ & $00(00)$ & Agreed \\
\hline 6 & $\begin{array}{l}\text { Frequent quarrel or fight that may turn violent } \\
\text { and lead to divorce is common among } \\
\text { cohabiting students }\end{array}$ & $116(58)$ & $56(28)$ & $28(14)$ & $00(00)$ & Agreed \\
\hline 7 & $\begin{array}{l}\text { Poor academic performance is likely to arise } \\
\text { from one or two of the cohabiting students }\end{array}$ & $108(54)$ & $68(34)$ & $16(08)$ & $08(04)$ & Agreed \\
\hline 8 & $\begin{array}{l}\text { Deep thoughts, psychological, health and } \\
\text { other related health issues may be common } \\
\text { among cohabiting students }\end{array}$ & $72(36)$ & $112(56)$ & $16(08)$ & $00(00)$ & Agreed \\
\hline
\end{tabular}

Table 2 revealed percentages of the consequences of cohabitation among students of Federal Polytechnic Offa as agreed.

\section{b. Discussion}

The first findings of the study revealed that freedom and poor or no monitoring/monitoring; fear of losing a lover, fear or insecurity in the school area, desire to practice couple's life, insufficient on-campus accommodation, the decline in moral and religious values, poverty/financial stress, and laziness are the causes of cohabitation among the students of Federal Polytechnic Offa. This finding is in agrees with the studies of Jiya and Alhassan (2019) and Onoyase (2020) which identified financial issues, inadequate on-campus accommodation, the decline in religious values or loss of religious inclination, abandonment of valued African culture, sexual gratification, desire to study each other for marriage, and higher tuition fee as factors responsible for cohabitation among tertiary institutions students. As seen in this study, it is evidently clear that on-campus accommodation is a cause of cohabitation but some students would still cohabit even if there is enough on-campus accommodation.

The second and last findings of this study revealed that unexpected pregnancies, drop out of school, sexually transmitted diseases (STDs), deep thoughts, trauma and other health-related issues, joining of bad gangs, abortion that may lead to complications, poor academic performance and quarrel or fight that may lead to separation. This finding coincides with the studies of Adeniyi (2019) and Ojewole and Okinduyo (2017) whose studies found out the consequences of cohabitation among students of tertiary institutions as including STDs, abortions, deaths, poor academic performance, depression, amongst others. That is, in conjunction with involvement in illegal or other criminal acts, students who cohabit try to live lives that will impress their partners or try to live by their partners' expectations, even if it is against their academics.

\section{CONCLUSION}

From the above, it can be seen that cohabitation is a menace as observed among the students of the federal polytechnic Offa as students have responded with a high percentage to the causes as seen in the study. The causes were seen to include a breakdown in moral values, freedom or no supervision, peer influence, fear of losing loved one, financial distress, practising married couples' life amongst others. As a result, some of the students feel they have gained freedom by leaving home to stay on their own and this lead some of them to doing things that even their parents have only been hearing about. These acts may have consequences on them which include death, abortions that may lead to complications, poor academic performance and or drop out of school, 
emotional, social and health effects, which some may be present while some are in the aftermath. Based on the finding of the study, it was recommended that;

a. The school management should try to increase the size of the on-campus hostel and make it compulsory for the students at least for the first sand last year to curb this menace

b. Parents and guardian counsellors should try as much as they can to educate their wards and warn them on the dangers of cohabitation on both their physical, social, academic and healthy life as students

c. Students of the polytechnic should desist from these acts as they are culpable of marring their future by inflicting social, health, emotional, psychological and other related problems to their lives.

\section{BIBLIOGRAPHY}

Adeniyi, A. O. (2019). The effects cohabitation on academic performance of the students I tertiary institutions Nigeria. International Journal of Sociology and Anthropology Research, 5 (2),10-15.

Arisukwu, C.O. (2014). Cohabitation among university of Ibadan undergraduate students. Journal of Humanities and Social Sciences. 3(5), 18-29.

Bumpass, L., \& Lu, H.(2000). Trends in Cohabitation and Implications for Children's Family Contexts in the US. Population Studies 54, 29-41

Daramola, S.O. (2006). Research methods and statistical analysis in education. Ado-Ekiti: Petoa Educational Publishers

Duyilemi, A.N., Tunde-Awe, B.M. \& Adekola L. O. (2018).Cohabitation in Nigeria tertiary institutions: a case study of Adekunle Ajasin University, Akungba-Akoko, Ondo State Nigeria. International Journal of Social Sciences \& Humanities. 4(2),19-29

Elise, E. (2004). Cohabitation: Just a Phase? Psychology Today 37, 28.

Ekpenyong, A.S. \& Ekpenyong, N.S. (2016). Perceived factors influencing premarital sexual practices among university students in Niger Delta University, Bayelsa state, Nigeria. Journal of Canadian Social Science, 12(11), 29-40

Jiya, J., \& Alhassan, D.Z. (2019). Factors influencing cohabitation among undergraduate students of federal university of technology Minna, Niger State, Nigeria: implications for counselling

Onoyase, A. (2020). Cohabitation among university students in Oyo state, South West Nigeria; causes and consequences: implications for counselling. Received: January 12, 2020 Accepted: February 18, 2020 Online Published: February 25, 2020 doi:10.5539/jel.v9n2pl40URL:https://doi.org/10.5539/jel.v9n2pl

Ojewola F.O., \& Okinduyo T.E. (2017). Prevalence and Factors Responsible for Cohabitation among Undergraduates of Adekunle Ajasin University, Ondo State, Nigeria. American Journal of Educational Research, 5(6), 650-654.

Risman, B., Hill, C., Rubin, Z. \& Peplau, L. (1981). Living together in college: implications for courtship. Journal of Marriage and the Family. 43. 7783.

The Federal Polytechnic Offa, (2021) Data 